\title{
REDACTIONEEL
}

\section{Mediation in strafzaken: nieuwe uitdagingen}

\author{
Annemieke Wolthuis, Renée Kool \& Bas van Stokkom
}

Wat een week. De dodelijke schietpartij in Utrecht, zo kort na de aanslag in Christ Church in Nieuw Zeeland. De leegte van de stad en de shock waarin de stad - en 'het achterland' - verkeerde, de rouw om de slachtoffers en alle commotie eromheen. Vervolgens de provinciale verkiezingen die gepaard gingen met veel verbale vijandelijkheden, met Forum voor Democratie als grote overwinnaar.

Toch was het ook een week van verbinding. Mensen zochten elkaar op, zoals steeds wanneer er erge dingen gebeuren, betonen hun respect en solidariteit aan slachtoffers en nabestaanden van zinloos geweld en roepen op tot vrede. Die saamhorigheid was er ook op vrijdag 22 maart 2019 toen we de Restorative Justice Academy in Amsterdam lanceerden (zie het signalement in dit nummer). Het kernteam van zeven professionals presenteerde trots een volwaardig aanbod van trainingen. Rob van Pagee, herstelrechtdenker en -doener van het eerste uur, verrichtte de opening door een lint door te knippenen. Hij memoreerde aan de oprichting van het Forum voor Herstelrecht in 2001 en de start van ons mooie tijdschrift. Pitches werden gehouden door trainingsinstituten van de Justitiepartners. We waren het er allemaal over eens: de tijd was snel gegaan en dat we nu in 2019 zover zijn gekomen, hoopten we destijds wel, maar we konden het niet voorzien. De vaart zit er dan toch - eindelijk - in!

Dat bleek ook op donderdag 21 maart, toen EénVandaag een uitzending wijdde aan de opkomst van mediation in strafzaken, met een mooi verslag van een slachtoffer dat door de ontmoeting meer inzicht heeft gekregen in het meisje dat haar van de fiets trok en ook in haar eigen handelen. Coördinator mediation in strafzaken en strafrechter Judith Uitermark lichtte samen met mediator Rebecca Leeuwenberg het proces toe. De journalisten benadrukten bovendien dat het huidige budget van $€ 1$ miljoen - hoe welkom ook - onvoldoende lijkt om het hele jaar mediations aan te kunnen bieden. Waar de strafrechter de deur open zet, dreigt die door een structureel tekort aan geld weer dicht te vallen, zoals Judith Uitermark signaleert in haar column. Ook Janny Dierx pakt de pen op om een lans te breken voor de financiële honorering van mediators. Die is nu ver onder de maat. In haar termen: 'Een gemiddelde loodgieter komt voor die 25 euro per uur zijn bed niet meer uit.'

Maar er is aanleiding tot diepere zorg. Want het herstelrechtelijke gedachtengoed krijgt dan wel steeds meer handen en voeten in de praktijk, maar er is nog veel te winnen. Met name, zo blijkt uit de bijdragen van Britt van der Plas en Bas van Stokkom, op het niveau van de eerste ronde besluitvorming. Britt studeerde vorig jaar af aan de VU met een scriptie over Mediation bij ZSM Midden-Nederland en bewerkte de onderzoeksresultaten tot een artikel over de rol van de ketenpart- 
ners en optimalisering van doorverwijzingen. Daaruit blijkt dat niet al die ketenpartners goed op de hoogte zijn van de mogelijkheden en dat er daardoor veel potentie verloren gaat. Dat geldt zeker voor de politie.

Uit het artikel van Bas van Stokkom spreekt eenzelfde zorg. Hij schrijft over het tekort aan aandacht voor en oriëntatie op het herstelrecht binnen de Nationale Politie. Daar ligt de focus nog immer, of wellicht opnieuw, op de traditionele handhaving via het strafrecht. Zijn bemiddeling en sociale zelfredzaamheid uit zicht, vraagt hij zich af. Bovendien heeft de omvorming tot de Nationale Politie, zo blijkt uit meerdere door hem aangehaalde onderzoeken, geleid tot een tamelijk in zichzelf gekeerde organisatie. De nadruk ligt op de strafrechtelijke doorstroom en er is weinig focus op preventie en versterking van de eigen kracht van burgers. Zeker, er zijn ook politiemensen die wel aandacht hebben voor herstelgericht werken, en die lieten zich ook horen op de bijeenkomst van de RJN Academy, maar overall past het nog te weinig in de huidige politiecultuur.

Dat staat op gespannen voet met de boodschap van de Raad van Europa, neergelegd in de nieuwe Aanbeveling concerning restorative justice in criminal matters van de Raad van Europa (CM/Rec(2018)8). Ivo Aertsen geeft een uitgebreide beschrijving, ook van de gemiste kansen waarvan de Aanbeveling getuigt. Hij vergelijkt de tekst met die van de Aanbeveling van 1999. De nieuwe Aanbeveling steekt in op een ruimere en meer algemene toepassing van het herstelrecht, en van het gebruik van herstelrechtelijke principes en benaderingen binnen het brede domein van de strafrechtsbedeling, dus ook aan de voorkant en in detentie. Zo is er sprake van een versterking van de rol van de strafrechtelijke autoriteiten en een striktere omschrijving van een aantal regels, met een strengere controle en toezicht op herstelrechtelijke praktijken. Maar de 'laatste klap met de hamer', ofwel het inschrijven van een recht op herstelrecht als zodanig werd niet gegeven. Een gemiste kans, concludeert Aertsen.

Er waren meer gemiste kansen, want ook op het op 21 februari gehouden congres 'Het slachtoffer en het strafproces: wat is de toekomst?', georganiseerd door het ministerie van Justitie en Veiligheid (minister van Rechtsbescherming), ontbrak het herstelrecht. Althans van officiële zijde, want vertegenwoordigers waren er genoeg en die lieten zich in de workshops en de wandelgangen goed horen. Die en andere observaties gaven voer voor het maken van kritische kanttekeningen bij de op reclameleest gestoelde presentatie van het ministeriële beleid. De minister van Rechtsbescherming en zijn ambtenaren waren tevreden, maar 'het (herstelrecht)volk' morde. Er was maar weinig ruimte voor herkenning in het eendimensionaal gepresenteerde beeld van slachtofferschap en ook het begrip rechtsbescherming - waar de minister toch zijn 'bestaansrecht' aan ontleent - bleek te zijn verengd tot onrechtstatelijke proporties. Dat moet, zo betoogt Kool, een volgend congres beter kunnen, zeker ook waar het de aandacht voor het herstelrecht betreft.

In dit nummer vindt u verder nog een verslag van Marit de Haan van de afsluitende conferentie van het project 'Implementing Restorative Justice with Child Victims' van de International Juvenile Justice Observatory (IJJO) en het Euro- 
pean Forum for Restorative Justice (EFRJ) in Brussel op 7 december 2018. Presentaties over het onderzoek en de praktijk rond jeugdige slachtoffers van misdrijven laten zien dat uitwisselingen van good practices tussen landen zeer bruikbaar zijn en dat ook juist voor jongeren een goede informatie en aparte regelgeving met specifieke aandacht voor kinderrechten van belang is.

We sluiten af met signalementen over strategieën voor verandering en over de Restorative Justice Academy. Het zijn initiatieven die gebruikmaken van de nieuwe Aanbeveling van de Raad van Europa en die uitgaan van het belang van kennisoverdracht, samenwerking en verbinding. 